\title{
Government Antipoverty Programmes and Small and Medium Enterprises Performance in Nigeria
}

\author{
Tonna, D. Edoko (M.Sc) \\ Department of Business Administration, \\ Tansian University, Umunya, Anambra State, Nigeria. \\ Chigbo D. Ngige (PhD) \\ Department of Business Administration, \\ Chukwuemeka Odumegwu Ojukwu University, Uli, Nigeria \\ Ikechukwu M. Okoli (M.Sc) \\ Department of Cooperative Economics and \\ Mgt, Nnamdi Azikiwe University (NAU), Awka, Nigeria
}

doi: 10.19044/esj.2017.v13n19p371 URL:http://dx.doi.org/10.19044/esj.2017.v13n19p371

\begin{abstract}
Over the years the Nigerian government has come up with a number of antipoverty programmes aimed at fighting poverty by financing her growth induced sector- SMEs, yet, the country is still witnessing rising levels of poverty, corruption, unemployment, low human capital development, inadequate commercial bank credit, high lending rate and low standard of education, thus, affecting the performance of small scale enterprises. In other to address the conundrum, this study examines the effect of government antipoverty programmes on small and medium enterprises' performance in Nigeria using econometric regression model of the Ordinary Least Square (OLS). From the regression analysis, the result showed that government antipoverty programmes, corruption, unemployment, human capital development, capital, lending rate and education conformed to the a priori expectations of the study and were statistically significant in explaining the SMEs' performance in Nigeria. The study recommends that: In order to enhance the success of government antipoverty programmes in Nigeria, the programme should be implemented through the local government on the platform of cooperative societies so that the target population will benefit from it. A blueprint for handling corrupt officials should be embedded in the policy framework of the programme before implementation. The programme should be targeted at unemployed youths with real identity rather than sinking back the funds into the pockets of corrupt officials. Every intending beneficiary should be subjected to training/skill acquisition programme and occasional workshop in the line of trade he/she wants to venture into.
\end{abstract}


Adequate funding at a good lending rate should be provided for any beneficiary of the programme in order to enhance the performance of the business in Nigeria.

Keywords: Antipoverty, Small and Medium Enterprises (SMEs), poverty, Performance, Regression Model.

\section{INTRODUCTION}

The contributions of Small and Medium Enterprises to the growth and development of an economy has been the focus of general interest and research, especially in developing countries due to their importance to the global economy (Offor, 2012; Muritala, Awolaja and Bako, 2012). According to Opafunso and Adepoju (2014), Small and Medium Scale Enterprise (SME) has proved to be a major tool adopted by the developed nations to attain socio- economic development. They further stated that in recent time, the small scale industrial sector is considered to be the backbone of modern day economy. Historical facts show that prior to the late 19th century, cottage industries, mostly small and medium scale businesses controlled the economy of Europe(Aremu, 2010). In the developing nations like Nigeria, the contributions of Small and Medium Enterprises to its growth and development can be felt in so many ways. According to Muritala et al, (2012), SMEs impact on the growth and development of an economy is felt by ways of greater utilisation of local raw materials, employment generation, encouragement of rural development, development of entrepreneurship, mobilisation of local savings, linkages with bigger industries, provision of regional balance by spreading investments more evenly, provision of avenue for self-employment and provision of opportunity for training managers and semi-skilled workers.

Despite the perceived impact of Small and Medium Enterprises on the growth and development of an economy as observed in the literature, and also the government effort at promoting SMEs in the country, the impact of SMEs to Gross Domestic Product (GDP) in Nigeria is reported to be low (Yusuf and Dansu, 2013; Adeloye, 2012). Arguably, this affects every other aspect of the economy. Eze, and Okpala (2015), captured the latent problem by stating that in spite of all the efforts by the government at federal, state, and local government levels, to ensure the growth of SMEs in Nigeria, SMEs continues to fail, thus, making the people to revolve in the vicious circle of poverty. Presently, businesses are closing down, unemployment is on the increase and poverty is ravaging the nation. However, despite the unique role played by Small and Medium Scale Enterprises (SMEs) in every economy, Nigeria inclusive, their performance in Nigeria is reported to be very low in terms of their survival rates and contributions to Gross Domestic Product 
(GDP) (Yusuf and Dansu, 2013; Adeloye, 2012). Anigbogu, okoli and Nwakoby (2015) stated that access to finance/capital remains a teething problem to SMEs. However, an accessible and a well supervised SMEs credit scheme for the development of the sector, appropriate environment and infrastructural facilities for SMEs development, good bank lending and interest rate to SMEs, regulated foreign exchange rate and positive economic reforms through monetary policies by the government could help to enhance SMEs performance.

A litany of poverty reduction programmes has been initiated by successive governments in Nigeria in an attempt to fight the country's rising poverty incidence (Ilesanmi \& Lasisi, 2015; Okoli, 2015; Ozoana, 2013; Ajakaiye \& Olomola, 1999; Ijaiya, 2007). Okoli (2015) enumerated the poverty reduction programmes to include: Agricultural Development Projects (ADP), River Basin Development Authority, Operation Feed the Nation (OFN), Green Revolution (GR), Family Economic Advancement Programme (FEAP), Family Support Programme (FSP), National Poverty Eradication Programme (NAPEP) and National Economic Empowerment and Development Strategy (NEEDS). Then came the Millennium Development Goals (MDGs), which was introduced as a new global partnership to tackle poverty - the global development dilemma. The Millennium Development Goals (MDGs) terminated in 2015 and another new global programme - Sustainability Development Goals (SDGs)- has been initiated but answers are yet to be given to the rising poverty incidence in Nigeria.

The Nigeria poverty profile began to trend after the oil boom in the 1970s (Okoli, 2015; Ozoana, 2013). Ozoana, 2013 further revealed that the 1980s saw the collapse of the oil price in the international market, thus, reducing the revenue of Nigeria. The country's neglect of the non-oil sector equally resulted in the dwindling of the country's revenue thereby increasing her poverty level. Okoli, (2015) and Ozoana (2013) again stated that the continuous downward trend in the oil prices in the international market increased the poverty level in Nigeria. The over-dependency on oil revenue and the inability to mobilize funds from non-oil sources also led to a serious decline in government revenue. The external reserves equally deteriorated and caused huge accumulated trade arrears which further limited government's effort in the provision of basic amenities and social facilities; and in investing in antipoverty programmes to improve on SMEs' performance.

Consequently, poverty profile in Nigeria rose from $28.1 \%$ in 1980 to $46.3 \%$ in 1985 . In 1992 it was $42.7 \%$ but sky rocked to $65.6 \%$ in 1996 and later nosed down to 54.4\% in 2004 (Okoli, 2015; Omadjohwoefe, 2011). Between 2004 and 2014, with an estimated population of about One Hundred 
and Sixty Million people (160million), about One Hundred and Twenty Million people were reported to be poor (National Bureau of Statistics [NBS], 2014). This poverty trend has continued to rise despite government's efforts in tackling it.

One sector that the government has supported massively in recent years is the SMEs' sector. The government antipoverty policy was aimed at promoting SMEs in Nigeria in order to increase employment and consequently reduce poverty, but the failure of government policies on these SMEs development has continued to raise doubts in the mind of the citizens about the sincerity of the government in the implementation of the SMEs' development policies (Anigbogu, Edoko, Okoli, 2016; Tijani, Oyeniyi \& Ogunyomi, 2012).

It is however believed and also attested to in the literature that SMEs have the potentials as "the engine of growth" and "catalysts for socioeconomic transformation of any country" (Onugu, 2005). Onugu (2005) further asserted that SMEs represent a veritable vehicle for the achievement of national economic objectives of employment generation and poverty reduction at low investment cost as well as the development of entrepreneurial capabilities including indigenous technology. Other intrinsic benefits of vibrant SMEs include access to infrastructural facilities occasioned by the existence of such SMEs in their surroundings, the stimulation of economic activities such as suppliers of various items and distributive trades for items produced and or needed by the SMEs, stemming from rural urban migration, enhancement of standards of living of the employees of the SMEs and their dependents as well as those who are directly or indirectly associated with them (Onugu, 2005). It is therefore imperative to promote the sector so as to tap into the sectors great potentials that have helped in transforming developed economies. It is against this back drop and in the light of the foregoing suggested measures that this study tries to juxtapose government antipoverty programmes and SMEs' performance in Nigeria by modelling the effect of government expenditure on poverty and SMEs' industrial growth rate while including other selected macroeconomic variables.

\section{Objectives of the Study}

The main objective of the study is to examine the effect of government antipoverty programmes on small and medium enterprises performance in Nigeria. Specifically, the study intends to ascertain the effect of government expenditure, corruption, unemployment, human capital development, capital, lending and education on the performance of small and medium enterprises in Nigeria. 


\section{REVIEW OF RELATED LITERATURE Conceptual Framework Concept of Poverty}

Poverty is in general, a state in which an individual or household is unable to meet the basic needs of life considered as minimum requirements to sustain livelihood in the given society. Some of these basic needs include adequate food, portable water, decent shelter, health, education, transportation, work, etc. In Nigeria, access to most of these basic needs is market determined (Aluko, 1975). Thus, income or disposal resources available to the individual or household invariably determine access to them. An individual household that does not have enough income to satisfy the minimum level of these basic needs in a given society is therefore said to be poor. The literature abounds with both economic and non-economic concepts of poverty. Some of these concepts of poverty include: absolute and relative poverty, subjective poverty and chronic and transitory poverty (Anyanwu 1997).

Absolute poverty definition starts by establishing a certain minimum levels of bundles of commodities that are fixed over time and individuals whose income or expenditure cannot meet such minimum requirements are considered poor. Relative poverty on the other hand, compares the welfare of those with the lowest amount of resources with others in the society/country without necessarily specifying minimum requirement in terms of bundles of goods/services. Subjective poverty definition requires the individuals (including the poor) to define what they consider to be a decent or minimally adequate standard of living. Transitory poverty is temporary, transient and short term in nature while chronic poverty is a long-term persistent poverty, the causes of which are largely structural. Measures of poverty include those that emphasise the incidence, depth and severity of poverty. Incidence of poverty is often determined through the establishment of a poverty line. This line separates the poor from the non-poor; hence how this line is measured can largely influence our interpretation of poverty and possibly the policies allocated for its eradication. Per capita income, real disposable income etc. and expenditure are often used as indicators of poverty (Imam, 1998). However, expenditure is often preferred to income due to the problem of under reporting of income (Ajakaiye \& Olomola, 1999).

Non-economic indicators of poverty include access to basic education, nutrition, health, safe drinking water and work. This enables us not only to separate the poor from the non-poor but also to differentiate among the poor themselves on the basis of these other dimensions. For instance, the non-income indicators may show significant difference with economic indicators. But the nature and extent of deprivation in terms of both economic and non-economic indicators would have to be determined to 
facilitate targeting through policy intervention (Ajakaiye \& Olomola 1999; Ogwumike, 2001).

\section{Related Empirical Literature}

Some related empirical literatures were reviewed in this section with the aim of identifying the missing gap in the works of previous researchers that necessitated this study. For instance, Oloyede (2014) examined the effect of poverty reduction programmes on economic development evidence from Nigeria. The study covered the period $1980-2010$, by analyzing time series data obtained from secondary sources using an econometric model of the Ordinary Least Square technique to measure the incidence of poverty. Findings reveal the existence of overall significant effect of poverty reduction on economic development in Nigeria. Oshewolo (2011) carried out a review of poverty reduction and the attainment of the MDGs in Nigeria: Problems and Prospects. The study observed that due to precarious socioeconomic ambience and the global publicity it generated, sub-Saharan Africa has become synonymous with poverty, and Nigeria hosts the largest population of poor people in the region. Although several ideas have been generated domestically to address the scourge but the persistence of poverty in large scale explains the inherent limitations in government interventionist measures. Consequent upon this, the inauguration of the MDGs, which represents an attempt at combating poverty through global partnership for development, appears to constitute the key to Nigeria's escape from poverty trap. Worrisomely however, the current progress towards the attainment of the goals is approximately at a snail's pace. Sokoto and Abdullahi (2013) carried out a study on strengthening Small and Medium Enterprises (SMEs) as a Strategy for Poverty Reduction in North Western Nigeria using T-test analysis. The study found that large enterprises contributed more in the area of employment provision than the SMEs going by the country - wide data. This contradicts the a priori assumption that small and medium enterprises do contribute to employment generation and use more indigenous technology than large corporations. Tersoo (2013) carried out an Assessment of National Poverty Eradication Programme on Wealth Creation in Benue State. The study examined the current strategies adopted by the Federal Government of Nigeria through National Poverty Eradication Programme (NAPEP) and the impact it had on the beneficiaries in Benue State. The explanatory- survey method was utilized for the collection of data through questionnaire administered on one hundred and nine (109) respondents selected from beneficiaries and key officials of NAPEP in six (6) local government areas of Benue State. The study suggested that the strategies employed by NAPEP had not made significant impact in improving the lives of beneficiaries in Benue State. The study also observed structural defects in the 
implementation strategies adopted by NAPEP. More so, corruption, poor funding and untimely release of funds, weak monitoring and impact assessment plans, and bad governance were major problems constraining the successful implementation of poverty reduction programmes in Nigeria. Dakyes and Mundi (2013) investigated the impact of anti-poverty programme on the development of rural areas of Nigeria using descriptive statistics; findings revealed that it had little positive impact on the well-being of the labour force due to alleged high rate of corruption among leaders and leakage of benefits to un-intended beneficiaries. In addition, the findings showed that poverty had serious setback on the development of the study area and by extension rural areas of Nigeria. Arogundade, Adebisi and Ogunro (2011) examined poverty alleviation programmes in Nigeria: A call for policy harmonisation with a view to come up with policy recommendation for effective and efficient implementation of such policies. In the course of the archaeological survey, it was revealed that governments in power often sought to introduce their own policy and in the process, any other policy inherited from successors are gradually either abandoned absolutely or rendered impotent. It was first thought that lack of succession planning was responsible, but in the process, it was observed that some governments even watch their baby programme dying prematurely to give birth to another. From close observation, it was observed that each of these programmes have different orientation and strategic focus. Bowale and Akinlo (2012) examined the determinants of small and medium scale enterprises performance and poverty alleviation in developing countries. This study specifically examined the socio-economic factors influencing the capacity of SMEs to alleviate poverty in the south-western part of Nigeria using appropriate descriptive statistics and inferential techniques. The results showed that majority $(75 \%)$ of surveyed SMEs operating in the southwest were microenterprises employing less than 10 workers while only (19\%) and $(6 \%)$ of the respondents engaged in small scale and medium scale enterprises, employing between 10 and 50 workers respectively. The results also showed that there was substantial increase (133\%) in number of SMEs owners that have grown in terms of employment generation from microenterprises to small scale and medium firms over the span of five years. They also found that business registration, business size, nature of business, sources of capital were the major factors determining both income and employment generation potentials of SMEs. Edoumiekumo, Karimo and Tombofa (2014) examined the incidence, depth and severity of poverty, and poverty correlates in Bayelsa state using the FGT decomposable class of poverty measures and a logit regression model as analytical tools on the 2009-2010 NLSS data. Results from the FGT model showed that about 25 percent of households had poor income. Results from the logit regression 
showed that agriculture and household size increase the probability that a household will be poor while dwelling in the urban area, being headed by a male, a naira increase in households per capita expenditure on education and per capita expenditure on health and a year's increase in the number of years spent schooling by household head reduce the probability that a household will be poor. The major poverty correlates in Bayelsa state were found to be per capita expenditure on education, per capita expenditure on health, years of schooling and household size. Ilesanmi and Lasisi (2015) examined the interface between government policies, human capital development and poverty reduction in Nigeria, with emphases on the policies of various regimes in Nigeria and how these policies have affected level of inequality and poverty in Nigeria. The study posited that poor implementation mechanisms were the major causes of failure of these policies, resulting in high level of poverty and inequality in the society. Ogundipe and Lawal (2013) examined the relationship among health, poverty and economic growth $1980-2011$. The results showed that the relationship between GDP per capital growth and the level of gross domestic was positive and statistically insignificant. The relationship between unemployment rate and economic growth was negative and statistically significant. Ozoana (2013) examined the impact of public spending on poverty reduction in Nigeria (1980-2011) using multiple regression analysis. The findings showed that government expenditure on health, education and transport, and communication was insignificant, while that on agriculture and water resources, and housing and environment was significant. Adamu (2012) examined the impact of public expenditure on human capital development in Kano state in the last twenty years. The results of the study showed that there was insufficient funding and inappropriate expenditure on education service; school buildings were inadequate and not in good shape and equity in providing education were neglected. Public expenditure was affirmed as been statistically significant in building human capital in the state. Asaju (2012) carried out a review on human capital development and poverty alleviation in Nigeria: A symbiotic overview. The study posited that investing in human capital through education was the best strategy for overcoming the developmental challenges in the country, especially poverty reduction. Alagba (2011) examined the nexus between human capital investment and poverty reduction in Nigeria using probit regression model. The major findings of the study revealed that expenditure on health and education reduced the probability that the household will be poor. Ogu (2011) investigated human capital development and poverty in Nigeria using panel data regression model from National Living Standard Survey 2008. The findings indicated that sex, age in years, mother education, and total expenditure on education, quintile and school enrolment significantly 
impacted on poverty reduction in Nigeria. Adawo (2010) used an econometric model to examine the contributions of primary education, secondary education, tertiary education, physical capital formation and health measured through total expenditure on health. In all, primary school input, physical capital formation and health were found to contribute to growth. Secondary school input and tertiary institutions were found to dampen growth. Isola and Alani (2008) examined the contribution of different measures of human capital development to economic growth in Nigeria using an econometric growth model which specified the growth of GDP as a function of labour, capital and policy reforms. They found that though little commitment had been accorded health when compared to education, empirical analysis showed that both education and health components of human capital development were crucial to economic growth in Nigeria. Kolawole and Omobitan (2014) empirically investigated the impact of agricultural sector on poverty reduction in the country over the period 1986 to 2012. Among econometric techniques employed for the research, the error correction mechanism (ECM) model revealed that food production index and government spending had negative impact on poverty headcount ratio in the country. Ogaboh, Akpanudoedehe and Stephen (2014) investigated the operations of non-governmental organizations (NGOs) in relation to the socioeconomic development of rural areas in Akwa Ibom State, Nigeria using Pearson Product Moment Correlation statistical technique. Results revealed that NGOs contributed immensely to rural development in Akwa Ibom State in the areas of health, education, economic and job creation. Okodua and Alege (2014) examined the various household welfare scenarios that will result from the imposition of shocks on import taxes in the Nigerian economy. The study found evidence that a policy of full or partial trade liberalization of the Nigerian economy will on overall have a mixed welfare implications for Nigerian households in the short run. While the policy will lead to a general improvement in consumption of goods and services as well as in real income of all households, it will at the same time hurt households by inducing unemployment in the two key sectors of agriculture and industry. Oni (2014) examined the role of agriculture in poverty reduction in Nigeria between 1980 and 2011 using Error Correction Mechanism. The result showed that per capita agricultural GDP, physical infrastructure per capita and social infrastructure per capita were positively and significantly related to poverty reduction while per capita nonagricultural gross domestic product (GDP) and inflation rate were negatively and insignificantly related to poverty reduction in Nigeria. Adepoju and Obayelu (2013) examined the effect of livelihood diversification on the welfare of rural households in Ondo State using descriptive statistics, multinomial logit and the logit regression models. Econometric analysis 
showed that household size, total household income and primary education of the household head were the dominant factors influencing the choice of livelihood strategies adopted. Income from non-farm activities, as well as income from a combination of non-farm and farming activities, impacted on welfare positively relative to income from farming activities. Akinbode (2013) assessed the poverty situation and its determinants among urban households in the south-west region of Nigeria using Foster, Greer and Thorbecke (FGT) index and the ordinary least square multiple regression analysis. The results revealed that majority of the households relied on water from boreholes for drinking, disposed refuse in undesignated places and patronized nearby drug stores when they are ill in place of proper diagnosis and treatment in hospitals. The FGT decomposition showed that 34 percent of the households were poor with a poverty gap and severity indices of 0.11 and 0.06 respectively. The study further revealed that educational level of heads, household size, and gender of heads, dependency ratio and access to credit exerted significant effect on household welfare. Kuku, Omonona, Oluwatayo and Ogunleye (2013) examined the effects of social capital on household welfare in Ekiti State, Nigeria using descriptive statistics, social capital indices and regression technique. Findings revealed that social capital positively affected household welfare. It also revealed that average age of the household heads members with monthly per capital income of Households attended two out of every three meetings and had high level $77 \%$. The index of heterogeneity at 23.7 indicated low level of diversity of the associations. Monthly cash contribution was highest for members in cooperative associations followed by religious association. An increase in the level of social capital would increase household per capita expenditure by $0.31 \%$. Disaggregation of social capital into its components showed that its effect on welfare was traceable to cash contribution and decision making of households in associations. Social capital was truly exogenous to household's welfare with no reverse causality. Olawuyi and Adetunji (2013) analysed the incidence, severity and the determinants of household poverty in Ogbomoso Agricultural Zone of Oyo State, Nigeria using poverty Indices and ordinary least square technique (OLS). The findings revealed that poverty is higher among households that have old heads, female heads, and large household size, engage in farming as the only occupation and have no formal education; poverty therefore rises with increase in household size while it reduces with increase in level of education, farm size and participation in non-farm jobs as alternative livelihood source (livelihood diversification). Gender, household size, years spent in school, farm size and non-farm jobs were found to be important and significant factors determining poverty in the study area. Adepoju and Oni (2012) examined the relationship between social capital and household welfare in the rural southwest of 
Nigeria using regression model of the Ordinary Least Square (OLS). Findings of the study revealed that age of respondents, sex, education, marital status; household size and farming status make a significant contribution to changes in household welfare. Also, the decision making index and meeting attendance are statistically significant and both are positively and negatively related to household welfare respectively. Results of the two stage least square revealed the exogeneity of social capital. However, the use of the control function model indicated that social capital was truly endogenous to household welfare due to non-linear interactions between social capital and unobservable variables. Ayoade and Adeola (2012) examined the effects of poverty on rural household welfare in Oyo State, Nigeria using correlation analysis. The findings of the study revealed that the major effect of poverty on household was low standard of living. A significant relationship was found between age, household size, level of income and the effects of poverty. Aiyedogbon and Ohwofasa (2012) examined poverty and youth unemployment in Nigeria, 1987-2011using the regression analysis. The results of the study revealed that unemployment, agricultural and service contributions to real GDP as well as population had positive determining influence on poverty level in Nigeria with only the agricultural sector statistically insignificant. On the other hand, the manufacturing sector contribution to real GDP and inflation rate exhibited negative relationship on poverty level in Nigeria with only the manufacturing sector appearing significant. Akerele and Adewuyi (2011) assessed household poverty and welfare among households in Ekiti State, Nigeria using a multistage sampling approach. Data collected were subjected to analyses such as descriptive statistics, poverty index and multiple regression analysis. The result revealed that 38.30 percent of the households covered by the study were poor and would have to mobilize financial resources up to $41.80 \%$ of 1 US Dollar (N130) per day (for each household member) to be able to escape poverty. Female headed households in the study area appeared to be more vulnerable to income poverty with poverty incidence, depth and severity of values 0.221 and $0.239,0.402$ and 0.191 , respectively. Highest levels of poverty were found among household with 7-9 dependants with values $1.00,0.715$ and 0.511 for the incidence, depth and severity of poverty respectively. Educational levels of household head and spouse, gender of household head and dependency ratio were factors that exacted significance influence on household welfare. Adewuyi and Hayatu (2011) examined the effect of poverty on food security of rural households in Adamawa State, Nigeria using the Logit Regression model. The result of the study revealed that there was a negative and statistically significant relationship between the household food and the poverty status of the household. Apata, Apata, Igbalajobi and Awoniyi (2010) examined the determinants of rural poverty in 
Nigeria using a Probit model on a sample of 500 smallholder farmers to establish factors that influenced probability of households escaping chronic poverty. Results showed that access to micro-credit, education, participation in agricultural workshops/seminars, livestock asset, and access to extension services significantly influenced the probability of households existing chronic poverty. On the other hand, female headed households and distance to the market increased the probability of persistence in chronic poverty. Adekoya (2014) examined the poverty status of farm households in Ogun State, Nigeria using a descriptive statistics, Foster, Greer and Thorbecke (FGT) poverty indices and Logit regression model. The results of the analysis revealed that majority $(70.9 \%)$ of the farm households do not have access to potable water; they live in mud buildings while the common toilet facility was the bush. The mean per capita consumption expenditure among the farm households was $9,103.85$ with the FGT poverty incidence, poverty gap and severity of poverty estimated to be $78.1 \%, 55.8 \%$ and $43.0 \%$ respectively. Poverty incidence was found to be higher among male headed $(60 \%)$ and farming (63.9\%) households and those having over five members (66.1\%).The logit regression further indicated that the likelihood of being poor were more with large households, non-educated farm households head and households without access to credit and other non-farm income.

From the empirical literature reviewed, studies relating to the effect of government antipoverty programmes on small and medium enterprises performance in Nigeria are rife with varying literary perspectives (Adekoya, 2014; Akaakohol and Aye, 2014; Edoumiekumo, Karimo and Tombofa, 2014; Kolawole and Omobitan, 2014; Ogaboh, Akpanudoedehe and Stephen, 2014; Oni, 2014; Adepoju and Obayelu, 2013; Adepoju and Obayelu 2013; Akinbode, 2013; Olawuyi and Adetunji, 2013; Adepoju and Oni, 2012; Ayoade and Adeola, 2012; Aiyedogbon and Ohwofasa, 2012; Akerele and Adewuyi, 2011; Apata et al, 2010; Babatunde, 2008; Oluwatayo, 2008). The gap in this study rest on a tripod stand. Firstly, most of the anti-poverty programmes investigated were not linked to small and medium enterprises performance in Nigeria. Secondly, most of the related studies were regional analysis carried out at state level. Thirdly, none of the related studies was carried out among SMEs using macroeconomic indicators of poverty reduction. These therefore create a knowledge and literature gap to be filled by this study.

\section{RESEARCH METHODOLOGY Model Specification}

This study examined government Antipoverty programme and the performance of small and medium enterprises by incorporating poverty, corruption, unemployment, human capital development, commercial bank 
credit, lending rate and education as explanatory variables while performance of small scale enterprises will be the dependent variable. Thus, the model for the study is stated as follows:

The structural form of the model

$\mathrm{SME}=\mathrm{f}(\mathrm{POV}, \mathrm{COR}, \mathrm{UNE}, \mathrm{HCD}, \mathrm{CAP}, \mathrm{LER}, \mathrm{EDU})$

... (1)

The mathematical form of the model

$\mathrm{SME} \quad=\beta_{0} \quad+\beta_{1} \mathrm{POV}+\beta_{2} \mathrm{COR}+\beta_{3} \mathrm{UNE}+\beta_{4} \mathrm{HCD}+\beta_{5} \mathrm{CBC}+\beta_{6} \mathrm{LER}+\beta_{7} \mathrm{EDU}$ (2)

The econometric form of the model

$\mathrm{SME}=\beta_{0}+\beta_{1} \mathrm{POV}+\beta_{2} \mathrm{COR}+\beta_{3} \mathrm{UNE}+\beta_{4} \mathrm{HCD}+\beta_{5} \mathrm{CBC}+\beta_{6} \mathrm{LER}+\beta_{7} \mathrm{EDU}+\mu_{\mathrm{i}}$ (3)

Where;

SME = Performance of small and medium scale enterprises proxied by industrial growth rate

POV = Government antipoverty programs measured by government expenditure on poverty

COR $=$ Corruption

$\mathrm{UNE}=$ Unemployment measured by unemployment rate

HCD $=$ Human capital Development

CAP $=$ Capital proxied by bank credits to SMEs

LER $=$ Lending rate

EDU $=$ Education measured by Government expenditure on education

$\mathrm{f}=$ Functional relationship

$\beta_{0}=$ the intercept or the constant

$\beta_{1}-\beta_{7}=$ the co-efficient of the explanatory variables

$\mu_{\mathrm{t}}=$ Stochastic error term.

\section{Method of data analysis}

The economic technique employed in the study is the ordinary least square (OLS). This is because the OLS computational procedure is simple. It is the best linear estimator among all unbiased estimators, it is efficient and have shown to have the smallest (minimum variance), thus, it is regarded as the best linear unbiased estimator (BLUE) in the classical linear regression (CLR) model. Basic assumptions of the OLS are related to the forms of the relationship among the distribution of the random variance $\left(\mu_{i}\right)$.

OLS is used exclusively to estimate the unknown parameters of a linear regression model. The Economic views (E-views) software was adopted for regression analysis. 


\section{Nature and source of data}

All data used in this research are secondary time series data which were sourced from the Central Bank of Nigeria $(\mathrm{CBN})$ annual statistical bulletin and National Bureau of Statistics (NBS) annual publications and reports.

\section{Empirical Analysis}

We test for stationarity using Augmented Dickey-Fuller (ADF) tests on the data. The ADF tests are done on level series, first and second order differenced series. The decision rule is to reject stationarity if ADF statistics is less than $5 \%$ critical value, otherwise, accept stationarity when ADF statistics is greater than $5 \%$ criteria value. The result of regression is presented in table 1 below. Establishing stationarity is essential because if there is no stationarity, the processing of the data may produce biased result. The consequences are unreliable interpretation and conclusions.

Table 1: Summary of ADF test results

\begin{tabular}{|c|c|c|c|c|c|c|}
\hline Variables & $\begin{array}{c}\text { ADF } \\
\text { Statistics }\end{array}$ & $\begin{array}{c}\text { Lagged } \\
\text { Difference }\end{array}$ & $\begin{array}{c}\mathbf{1 \%} \text { Critical } \\
\text { Value }\end{array}$ & $\begin{array}{c}\mathbf{5 \%} \text { Critical } \\
\text { Value }\end{array}$ & $\begin{array}{c}\mathbf{1 0 \%} \text { Critical } \\
\text { Value }\end{array}$ & $\begin{array}{c}\text { Order of } \\
\text { Integration }\end{array}$ \\
\hline SME & -8.406982 & 1 & -3.646342 & -2.954021 & -2.615817 & $I(1)$ \\
\hline POV & 7.139741 & 1 & -3.646342 & -2.954021 & -2.615817 & $I(1)$ \\
\hline COR & -7.758980 & 1 & -3.646342 & -2.954021 & -2.615817 & $I(1)$ \\
\hline UNE & -5.944646 & 1 & -3.646342 & -2.954021 & -2.615817 & $I(1)$ \\
\hline HCD & -5.699368 & 1 & -3.646342 & -2.954021 & -2.615817 & $I(1)$ \\
\hline CAP & -3.911920 & 1 & -3.646342 & -2.954021 & -2.615817 & $I(1)$ \\
\hline LER & -6.119729 & 1 & -3.646342 & -2.954021 & -2.615817 & $I(1)$ \\
\hline EDU & -4.185272 & 1 & -3.646342 & -2.954021 & -2.615817 & $I(1)$ \\
\hline
\end{tabular}

Source: Researcher computation

Evidence from unit root table above shows that none of the variables are stationary at level difference that is, $I(0)$, rather all the variables are stationary at first difference, that is, $I(1)$. Since the decision rule is to reject stationarity if ADF statistics is less than 5\% critical value, and accept stationarity when ADF statistics is greater than $5 \%$ criteria value, the ADF absolute value of each of these variables is greater than the $5 \%$ critical value at their first difference but less than $5 \%$ critical value in their level form. Therefore, they are all stationary at their first difference integration.

\section{Summary of Johansen Cointegration Test}

Cointegration means that there is a correlationship among the variables. Cointegration test is done on the residual of the model. Since the unit root test shows that all the variables are stationary at first difference, $I(1)$, we therefore test for cointegration among these variables. The result is summarized in the tables below for Trace and Maximum Eigen-value cointegration rank test respectively. 
Table 2: Summary of Johansen Cointegration Test

Unrestricted Cointegration Rank Test (Trace)

\begin{tabular}{lllll}
\hline \hline $\begin{array}{l}\text { Hypothesized } \\
\text { No. of CE(s) }\end{array}$ & Eigenvalue & $\begin{array}{l}\text { Trace } \\
\text { Statistic }\end{array}$ & $\begin{array}{l}0.05 \\
\text { Critical Value }\end{array}$ & Prob.** \\
\hline \hline None * & 0.962211 & 284.3043 & 159.5297 & 0.0000 \\
At most 1 $*$ & 0.866441 & 176.2046 & 125.6154 & 0.0000 \\
At most 2 $*$ & 0.698474 & 109.7687 & 95.75366 & 0.0038 \\
At most 3* & 0.553389 & 70.20504 & 69.81889 & 0.0466 \\
At most 4 & 0.531286 & 49.60483 & 47.85613 & 0.0185 \\
At most 5 & 0.318672 & 31.59865 & 29.79707 & 0.0220 \\
At most 6 & 0.118734 & 5.936150 & 15.49471 & 0.7031 \\
At most 7 & 0.052083 & 1.765103 & 3.841466 & 0.1840 \\
\hline \hline
\end{tabular}

Trace test indicates 6 cointegrating eqn(s) at the 0.05 level

* denotes rejection of the hypothesis at the 0.05 level

**MacKinnon-Haug-Michelis (1999) p-values

Unrestricted Cointegration Rank Test (Maximum Eigenvalue)

\begin{tabular}{lccll}
\hline \hline $\begin{array}{l}\text { Hypothesized } \\
\text { No. of CE(s) }\end{array}$ & Eigenvalue & $\begin{array}{l}\text { Max-Eigen } \\
\text { Statistic }\end{array}$ & $\begin{array}{l}0.05 \\
\text { Critical Value }\end{array}$ & Prob.** \\
\hline \hline None * & 0.962211 & 108.0996 & 52.36261 & 0.0000 \\
At most 1 * & 0.866441 & 66.43590 & 46.23142 & 0.0001 \\
At most 2 $*$ & 0.698474 & 41.56370 & 40.07757 & 0.0270 \\
At most 3 & 0.553389 & 36.60021 & 33.87687 & 0.0054 \\
At most 4 & 0.531286 & 29.00618 & 27.58434 & 0.0332 \\
At most 5 & 0.318672 & 12.66250 & 21.13162 & 0.4838 \\
At most 6 & 0.118734 & 4.171048 & 14.26460 & 0.8409 \\
At most 7 & 0.052083 & 1.765103 & 3.841466 & 0.1840 \\
\hline \hline
\end{tabular}

Max-eigenvalue test indicates 5 cointegrating eqn(s) at the 0.05 level

$*$ denotes rejection of the hypothesis at the 0.05 level

**MacKinnon-Haug-Michelis (1999) p-values

\section{Source: Researcher computation}

Table 2 indicates that trace have 5 cointegrating variables in the model while Maximum Eigen value indicated 5 cointegrating variables. Both the trace statistics and Eigen value statistics reveal that there is a long run relationship between the variables. That is, the linear combination of these variables cancels out the stochastic trend in the series. This will prevent the generation of spurious regression results. Hence, the implication of this result is a long run relationship between SME performance and other variables used in the model. 


\section{Presentation of Result}

The result of the regression test is summarised in table 3 below.

Table 3: Summary of regression results

Dependent Variable: SME

Method: Least Squares

Sample: 19812015

Included observations: 35

\begin{tabular}{cclcc}
\hline \hline Variable & Coefficient & Std. Error & t-Statistic & Prob. \\
\hline C & 3.092617 & 1.536473 & 4.012803 & 0.0002 \\
POV & 2.686112 & 3.623436 & -5.657703 & 0.0000 \\
COR & -0.870444 & 0.487557 & -3.785317 & 0.0024 \\
UNE & -0.059790 & 0.046957 & -3.273301 & 0.0038 \\
HCD & 28.28426 & 4.975277 & 5.684961 & 0.0000 \\
CAP & 1.470521 & $1.74 \mathrm{E}-05$ & 3.849021 & 0.0012 \\
LER & 0.249093 & 0.050856 & 4.898021 & 0.0000 \\
EDU & 5.906619 & 4.475242 & 6.320242 & 0.0000 \\
\hline \hline R-squared & 0.935738 & F-statistic & 56.16508 \\
Adjusted R-squared & 0.919078 & Prob(F-statistic) & 0.000000 \\
S.E. of regression & 0.794476 & Durbin-Watson stat & 1.734666 \\
\hline \hline
\end{tabular}

Source: Researcher computation

\section{Evaluation of Findings}

To discuss the regression results as presented in table 3 , we employ economic a priori criteria, statistical criteria and econometric criteria.

\section{Evaluation based on economic a priori criteria}

This subsection is concerned with evaluating the regression results based on a priori (i.e., theoretical) expectations. The sign and magnitude of each variable coefficient is evaluated against theoretical expectations.

From table 3, it is observed that the regression line have a positive intercept as presented by the constant $(c)=3.092617$. This means that if all the variables are held constant or fixed (zero), SME performance will be valued at 3.092617. Thus, the a-priori expectation is that the intercept could be positive or negative, so it conforms to the theoretical expectation.

It is observed in Table 3 that government antipoverty programs, human capital development, capital, lending rate and education have a positive impact on SMEs performance in Nigeria. This means that government antipoverty programs, human capital development, capital, lending rate and education are developed and improve, it will bring about more SMEs performance in Nigeria. On the other hand, corruption and unemployment has a negative impact on SMEs performance in Nigeria. 
Thus, increase in corruption and unemployment will bring about a decline in SMEs performance in Nigeria and vice versa.

From the regression analysis, it is observed that all the variables conform to the a priori expectation of the study. Thus, table 4 summarises the a priori test of this study.

Table 4: Summary of economic a priori test

\begin{tabular}{|c|c|c|c|c|c|}
\hline \multirow[t]{2}{*}{ Parameters } & \multicolumn{2}{|c|}{ Variables } & \multirow{2}{*}{$\begin{array}{c}\text { Expected } \\
\text { Relationships }\end{array}$} & \multirow{2}{*}{$\begin{array}{c}\text { Observed } \\
\text { Relationships }\end{array}$} & \multirow[t]{2}{*}{ Conclusion } \\
\hline & Regressand & Regressor & & & \\
\hline$\beta_{0}$ & SME & Intercept & $+/-$ & + & Conform \\
\hline$\beta_{1}$ & SME & POV & + & + & Conform \\
\hline$\beta_{2}$ & SME & COR & - & - & Conform \\
\hline$\beta_{3}$ & SME & UNE & - & - & Conform \\
\hline$\beta_{4}$ & SME & HCD & + & + & Conform \\
\hline$\beta_{5}$ & SME & CAP & + & + & Conform \\
\hline$\beta_{6}$ & SME & LER & + & + & Conform \\
\hline$\beta_{7}$ & SME & EDU & + & + & Conform \\
\hline
\end{tabular}

Source: Researchers compilation

\section{Discussion based on statistical criteria}

This subsection applies the $\mathrm{R}^{2}$, adjusted $\mathrm{R}^{2}$ and the $\mathrm{f}$-test to determine the statistical reliability of the estimated parameters. These tests are performed as follows:

From our regression result, the coefficient of determination $\left(\mathrm{R}^{2}\right)$ is given as 0.935738 , which shows that the explanatory power of the variables is extremely high and/or strong. This implies that $94 \%$ of the variations in the performance of small and medium enterprises are being accounted for or explained by the variations in government antipoverty programms, corruption, unemployment, human capital development, capital, lending rate and education in Nigeria, while other determinants of SMEs performance not captured in the model explain just $6 \%$ of the variation in small and medium enterprise performance in Nigeria.

The adjusted $\mathrm{R}^{2}$ supports the claim of the $\mathrm{R}^{2}$ with a value of 0.919078 indicating that $92 \%$ of the total variation in the dependent variable (small and medium enterprise performance is explained by the independent variables (the regressors)). Thus, this supports the statement that the explanatory power of the variables is extremely high and strong.

The F-statistic: The F-test is applied to check the overall significance of the model. The F-statistic is instrumental in verifying the overall significance of an estimated model. In other words, there is significant impact between the dependent and independent variables in the model. 


\section{Discussion based on econometric criteria}

In this subsection, the following econometric tests are used to evaluate the result obtained from our model: autocorrelation, heteroscedasticity and multicolinearity.

\section{Test for Autocorrelation}

Using Durbin-Watson (DW) statistics which we obtain from our regression result in table 3 , it is observed that DW statistic is 1.734666 or approximately 2 . This implies that there is no autocorrelation since $\mathrm{d}^{*}$ is approximately equal to two. 1.734666 tends towards two more than it tends towards zero. Therefore, the variables in the model are not autocorrelated and that the model is reliable for predications.

\section{Test for Heteroscedasticity}

This test is conducted using the white's general heteroscedascity test. The hypothesis testing is thus:

$\mathrm{H}_{0}$ : There is a heteroscedasticity in the residuals

$\mathrm{H}_{1}$ : There is no heteroscedasticity in the residuals

Decision rule: Reject $\mathrm{H}_{0}$ if $\mathrm{f}$-statistics is significant. Otherwise, accept at 5\% level of significance. Hence, since the F-test is significant, we reject $\mathrm{H}_{0}$ and accept $\mathrm{H}_{1}$ that the model has no heteroscedasticity in the residuals and therefore, the data is reliable for predication.

\section{Test for Multicolinearity}

This means the existence of an exact linear relationship among the explanatory variable of a regression model. This will be used to check if collinearity exists among the explanatory variables. The basis for this test is the correlation matrix obtained using the series. The result is presented in appendix 5 and summarized in table 4.5 below.

Decision Rule: From the rule of Thumb, if correlation coefficient is greater than 0.8, we conclude that there is multicolinearity but if the coefficient is less than 0.8 there is no multicolinearity. We therefore, conclude that the explanatory variables are not perfectly linearly correlated.

\section{Conclusion and Recommendations}

The study attempted to explain the effect of government antipoverty programmes on the performance of small and medium enterprises in Nigeria from 1981-2015 using Ordinary least Square (OLS) technique method. All data used were secondary data obtained from the Statistical Bulletin of Central Bank of Nigeria (CBN) and National Bureau of Statistics (NBS) annual publications. In executing the study, the OLS techniques was applied after determining the stationarity of our variables using the ADF Statistic, as 
well as the cointegration of variables using the Johansen approach. It was discovered that the variables are stationary and there is a long term relationship among the variables in the model. From the result of the OLS, it is observed that government antipoverty programs, human capital development, capital, lending rate and education have a positive impact on SMEs performance in Nigeria. This means that if government antipoverty programs, human capital development, capital, lending rate and education are developed and improve, it will bring about more SMEs performance in Nigeria. On the other hand, corruption and unemployment has a negative impact on SMEs performance in Nigeria. Thus, increase in corruption and unemployment will bring about a decline in SMEs performance in Nigeria and vice versa. The study revealed that government antipoverty programs, corruption, unemployment, human capital development, capital, lending rate and education are good and major determinants of SMEs performance in Nigeria. From the regression analysis, the result showed that government antipoverty programs, corruption, unemployment, human capital development, capital, lending rate and education conform to the a priori expectation of the study and are statistically significant in explaining the SMEs performance in Nigeria. The F-test conducted in the study showed that the model has a goodness of fit and is statistically different from zero. In other words, there is a significant impact between the dependent and independent variables in the model. Finally, the study showed that a long run relationship exists among the variables. Both $\mathrm{R}^{2}$ and adjusted $\mathrm{R}^{2}$ showed that the explanatory power of the variables is extremely high and/or strong in explaining the SMEs performance in Nigeria.

In the light of the above empirical findings in the analysis carried out, the following recommendations are made: In order to enhance the success of government antipoverty programs in Nigeria, the programme should be implemented through the local government on the platform of cooperatives so that the target population will benefit from it. A blueprint for handling corrupt officials should be embedded in the policy framework of the programme before implementation. The programme should be targeted at unemployed youths with real identity rather than sink back funds into the hands of corrupt officials. Every intending beneficiary should be subjected to training/skill acquisition programme and occasional workshop in the line of trade he/she wants to venture into. Adequate funding at a good lending rate should be provided by government for any beneficiary of the programme so as to enhance performance of business in Nigeria.

\section{References:}

1. Adamu, S. (2012). The impact of public expenditure on human capital development in Kano State (1990 - 2009). A published M.Sc. 
Thesis. Department of Economics. Faculty of Ahmadu Bello University, Zaria-Nigeria.

2. Adawo, M. A. (2010). Has education (human capital) contributed to the economic growth of Nigeria? Journal of Economics and International Finance. 3(1), 46-58.

3. Adepoju, A. O. \& Obayelu, O, A. (2013). Livelihood diversification and welfare of rural households in Ondo State, Nigeria. Journal of Development and Agricultural Economics. 5(12), 482-489.

4. Adepoju, A.A. \& Oni, O.A. (2012). Investigating Endogeneity Effects of Social Capital on Household Welfare in Nigeria: A Control Function Approach. Quarterly Journal of International Agriculture, 51(1), 73-96.

5. Adekoya, O. A. (2014). Analysis of Farm Households Poverty Status in Ogun States, Nigeria. Asian Economic and Financial Review, 4(3), 325-340.

6. Adeloye, L. Federal Government Unveils Strategies to Reposition SMEs. The Punch. Retrieved September 21, 2012, from http://www.punch.ng, 2012, May 11.

7. Adewuyi, K. A. \& Hayatu, Y. (2011). Effect of Poverty on Food Security of Rural Households in Adamawa State, Nigeria, Journal of Environmental Issues and Agriculture in Developing Countries, 3(1), 150-156.

8. Aiyedogbon, J. O. \& Ohwofasa, B. O. (2012). Poverty and youth Unemployment in Nigeria, 1987-2011, International Journal of Business and Social Science, 3( 20),269-279.

9. Ajakaiye, D.O and Olomola, S.A (1999) "Conceptual and Methodological Issues in Poverty Alleviation" CBN Bullion. 23(4).

10. Akerele, D. \& Adewuyi, S.A. (2011). Analysis of Poverty Profiles and Socioeconomic Determinants of Welfare among Urban Households of Ekiti State, Nigeria. Current Research Journal of Social Sciences, 3(1), 1-7.

11. Akinbode, S. O. (2013). Profiles and Determinants of Poverty among Urban Households in South-West Nigeria. American Journal of Economics, 3(6): 322-329.

12. Alagba, C. A. (2011). Human capital investment and poverty reduction nexus in Nigeria. A published Master of Science (M.Sc) degree thesis in Economics. Department of economics University of Nigeria Nsukka.

13. Aluko, S.A: (1975) "Poverty: its remedies" in poverty in Nigeria. (Proceedings of the 1975 Annual Conference of the Nigerian Economic Society, Ibadan. 
14. Anigbogu, T. U., Edoko, T. D. \& Okoli, I. M. (2016). Foreign Direct Investment and Poverty Reduction in Nigeria. International Journal of Business and Management Invention, 5(6), 19-28.

15. Anigbogu, T. U., Okoli, I.M \& Nwakoby, N.P (2015). Financial intermediation and small and medium enterprises performance in Nigeria (An aggregated analysis: 1980-2013). European Scientific Journal,11(28), 257-272.

16. Anyanwu, J.C (1997) Poverty in Nigeria: concepts, measurement and determinants. In .O. Teriba (ed.), Poverty alleviation in Nigeria. Ibadan: Nigerian Economic Society.

17. Apata, T. G., Apata, O. M., Igbalajobi, O. A. \& S. Awoniyi, M. O. (2010). Determinants of rural poverty in Nigeria: Evidence from small holder farmers in South-western, Nigeria. Journal of Science and Technology Education Research, 1(4), 85 - 91.

18. Akinbode, S. O. (2013). Profiles and Determinants of Poverty among Urban Households in South-West Nigeria. American Journal of Economics, 3(6), 322-329.

19. Anigbogu, T. U., Onwuteaka, C. I. Anyanwu, K. N. \& Okoli, M. I. (2014). Impact of household composition and anti-poverty Programmes on welfare in Nigeria: A comparative analysis. European Journal of Business and Social Sciences, 3(5), 23-36.

20. Aremu, M.A. (2010). Small and Medium Scale Enterprises as a Means of Employment Generation ND Capacity Building in Nigeria, A paper Presented at the International Conference on Management and Enterprise Development on, "Intellectual and New Strategies for Sustainability Development of the Third World" Held at Conference Center, University of Ibadan, Ibadan, Nigeria, October 5 - 8, pp. 3948.

21. Arogundade, K. K., Adebisi, S. O. \& Ogunro, V. O. (2011). Poverty Alleviation Programmes in Nigeria: A Call for Policy Harmonisation. European Journal of Globalization and Development Research, 1(1), 42-52.

22. Ayoade, A. R \& Adeola R.G (2012). Effects of Poverty on Rural Household Welfare in Oyo State, Nigeria. Global Journal of Science Frontier Research Agriculture \& Biology, 12(4), 45-52.

23. Babatunde, R.O. (2008). Income Inequality in Rural Nigeria: Evidence from Farming Households Survey Data. Australian Journal of Basic and Applied Sciences, 2(1), 134-140.

24. Eze, T. C., Okpala, C. S. (2015). Quantitative Analysis of the Impact of Small and Medium Scale Enterprises on the Growth of Nigerian Economy. International Journal of Development and Emerging Economics, 3(1), 26-38. 
25. Ijaiya, G.T (2007). Poverty alleviation programmes in H. Saliu, E. Amali and R. Olawepo, (eds) Nigeria's reform programme: issues and challenges. Lagos: Concept Publishing.

26. Ilesanmi, O. A. \& Lasisi, F. A. (2015). The interface between government policies, human capital development and poverty reduction in Nigeria. European Journal of Business and Innovation Research, 3(4), 11-25.

27. Isola, W. A. \& Alani, R. A. (2008). Human capital development and economic growth: Empirical evidence from Nigeria. Asian Economic and Financial Review, 2(7), 813-827.

28. Kolawole, B. O. \& Omobitan, O A. (2014). Raging Poverty and Agricultural Output in Nigeria: An Empirical Investigation. Journal of Economics and Sustainable Development, 5(6), 63-72.

29. Muritala, T. A., Awolaja, A.M. and Bako, Y. A. (2012). Impact of Small and Medium Enterprises on Economic Growth and Development. American Journal of Business and Management, 1(1), 18-22.

30. NBS (National Bureau of Statistics) (2012): Poverty Profile for Nigeria. National Bureau of

Statistics, Lagos. Available online:http://www.nigerianstat.gov.ng/Co nnections/poverty/POVPreliminary.pdf.

31. Offor, S. U. (2012). The Impact of Small and Medium Scale Industries on the Economic Growth of Nigeria (1986 - 2010). A project submitted in partial fulfillment of the requirements for the award of Bachelor of Science (B.Sc.) Degree in economics.

32. Ogaboh, A. A. M. , Akpanudoedehe, J. J. \& Stephen, O. (2014). Financing Poverty Reduction Programmes in Rural Areas of Nigeria: The Role of Non-Governmental Organisations (NGOs). International Journal of Democratic and Development Studies (IJDDS), 2(1), 1-16.

33. Ogundipe, M. A. \& Lawal, N. A. (2013). Health, poverty reduction and human capital development in Nigeria. International Journal of Management Sciences and Business Research, 2(12), 159-166.

34. Ogwunike, F (2001). Poverty alleviation appraisal of 2001 budget. Business Times. April 9 - 15, 16-17.

35. Okodua, H. and Alege, P. O. (2014). Household Welfare Impact of Trade Liberalization in Nigeria: A Computable General Equilibrium Model. Journal of Economics and Sustainable Development, 5(28), 41-52.

36. Okoli, I. M. (2015). Responsiveness of household welfare to antipoverty programmes among members of agricultural cooperative societies in Anambra State, Nigeria. Unpublished Ph.d Proposal. 
Department of Cooperative Economics \& Management Nnamdi Azikiwe University, Awka, Anambra State, Nigeria.

37. Olawuyi, S. O. \& Adetunji, M. O. (2013). Assessment of Rural Households Poverty in Nigeria: Evidence from Ogbomoso Agricultural Zone of Oyo State, Nigeria. Journal of Scientific Research \& Reports, 2(1), 35-45.

38. Oloyede, B. B. (2014). Effect of Poverty Reduction Programmes on Economic Development Evidence from Nigeria. Arabian Journal of Business and Management Review, 4(1), 26-37.

39. Oluwatayo, I.B. (2008). Explaining Inequality and Welfare Status of Households in Rural Nigeria. Evidence from Ekiti State. Humanity \& Social Sciences Journal, 3(1), 70-80.

40. Omadjohwoefe, O. S. (2011). Evolving Poverty Profile and the Millennium Development Goals In Nigeria, JORIND, 9(1), 177-185.

41. Oni, L. B. (2014). An Assessment of Agriculture and Poverty Reduction Nexus in Nigeria. Journal of African Macroeconomic Review, 4(1),265-284.

42. Onugu, B. A. N. Small and Medium Enterprises (SMEs) in Nigeria: Problems and Prospects. Being a Dissertation Submitted to the St. Clements University in Partial Fulfilment of the Requirements for the Award of the Degree of Doctor of Philosophy in Management, 2005.

43. Opafunso, Z. O. and Adepoju, O. O. (2014), The Impact of Small and Medium Scale Enterprises on Economic Development of Ekiti State, Nigeria. Journal of Economics and Sustainable Development, 5(16), 115-122.

44. Oshewolo, S. (2011). Poverty Reduction and the Attainment of the MDGs in Nigeria: Problems and Prospects. International Journal of Politics and Good Governance, 2(2), 1-22.

45. Ozoana, I. C. (2013). The impact of public spending on poverty reduction in Nigeria (1980-2011). A published B.Sc project, Department of Economic, Caritas University Amorji-Nike Emene, Enugu state.

46. Sokoto, A. A. and Abdullahi, Y. Z. (2013). Strengthening Small and Medium Enterprises (SMEs) as a Strategy for Poverty Reduction in North Western Nigeria. American Journal of Humanities and Social Sciences, 1(3). 190-203.

47. Tersoo, K. S. (2013). An Assessment of National Poverty Eradication Programme on Wealth Creation in Benue State. European Journal of Business and Management, 5(19), 28-4.

48. Tijani, A. A., Oyeniyi, G. O. and Ogunyomi, O.O. (2012). The Impact of Technical Entrepreneurial Skills on Employment Generation in Small and Medium Scale Enterprises in Lagos State, 
Nigeria: A Comparative Analysis. European Journal of Humanities and Social Sciences, 13 (1), 604-622.

49. Yusuf, T. O. \& Dansu, F. S. SMEs, Business Risks and Sustainability in Nigeria. European Journal of Business and Social Sciences, 2(9), 76-94, 2013. 